Ann. Génét. Sél. anim., I977, 9 (2), 251-257.

\title{
Heterosis in Fayoumi strain incrossing
}

\author{
M. SOLTAN, F. H. ABDOU, M. ABD-ELLATIF and H. AYOUB $\left({ }^{*}\right)$ \\ Faculty of Agric., Tanta Univ., Shebin El-Kom, Egypt.
}

\section{Summary}

Many experiments have proved the superiority of hybrids resulting from incrossing of mbred lines, which have been utilized commercially in poultry production. The aim oi this experiment was to study the effect of incrossing inbred lines of Fayoumi chickens upon their combinability. The results can be summarized as follows: control.

The fertility percentage was 96.7 in $\mathrm{L}_{25} \times \mathrm{L}_{50}$ incross comparing with 92.9 in outbred

Some incrosses (L25 $\times$ L 37.5) secured considerable positive effect on hatchability which reached $143.7 \%$ in relation to the control.

At 16 weeks of age, the viability percentage of the control chicks was 67.5 , while it reached 84.6 in $\mathrm{L}_{25} \times \mathrm{L}_{37.5}$ by incrossing.

The heavier incross $\mathrm{L}_{25} \times \mathrm{L}_{37.5}$ had body weight equal to II 8 , I I 2 and $\mathrm{x}_{03} \%$ in relation to the control at 4,8 and $\mathrm{I} 6$ weeks of age, respectively. Heterosis in body weight became less obvious as chicks advanced in age and alleles responsible for early growth rate showed a great response to incrossbreeding.

Incrossbreeding improved feed utilization of Fayoumi chicks.

These results show the possibility for improving the native breed by incrossing and detecting the most efficient incrossbreds.

\section{Introduction}

Superior vigor of hybrids resulting from inbred line crosses has been utilized commercially in the production of chickens for both meat and eggs. Most of the studies dealing with incrossing showed that heterosis produced considerable positive effect on economical characters in chickens.

RizK (I967) working on Fayoumi incrosses reported that incrossing increased hatchability. Similar findings on feed efficiency, body weight and viability in other breeds were reported for instance by MARShall and QUISENBERRy (I959) and COLE and Hutt (1962).

(*) Faculty of Agric., Ain Shams Univ. 


\section{Material and methods}

The main objective of the present investigation was to study the effect of incrossing on some economic traits in Fayoumi chicks. Full-sib, half-sib and first cousin matings were used to get different inbreding intensities. Fayoumi sires and dams were mated in family pens supplied with trap nests, and pedigree chicks were used to consist different inbred lines during the experimental period (i.e. I97I-I975).

The data were collected by using 15 females mated to 2 sires for each type of cross. Thus I 8 sires and I35 dams were used in this experiment, giving 769 offspring. For the "control " group 205 individuals were obtained. The experiment was carried out during february 1975 and 4 hatches were available. All the chicks were reared in batteries in the same conditions using a diet of a standard type.

The eontrol chicks (outbreds) were resulted randomly from a flock mating system. Three inbred lines (having inbreeding coefficients $25,37,5$ and $50 \%$ ) had been incrossed in all possible combinations.

Results were subjected to statistical analysis using the method of analysis of variance (SNEDECOR, I959).

\section{Results and discussion}

\section{Effect of incrossing on fertility}

Data in Table I summarize the effect of incrossing on fertility of Fayoumi chicks. The fertility percentage in the control chicks was 92,9 , while it was improved in $\mathrm{L}_{25} \times \mathrm{L}_{50}$ incross and reached 96.7 . The reciprocal incross $\left(\mathrm{L}_{50} \times \mathrm{L}_{25}\right.$ ) had the lowest fertility percentage $(69.4 \%$ ). Moreover, all the incrosses having L25 as a male had the highest fertility percentages, while their reciprocal incrosses had the poorest percentages. These results suggest a possible effets of the inbreeding coefficient of the male line on fertility.

TABLE I

Effect of incrossing on fertility percentage

Effet de la consanguinité suivie de croisement sur le pourcentage de fertilité

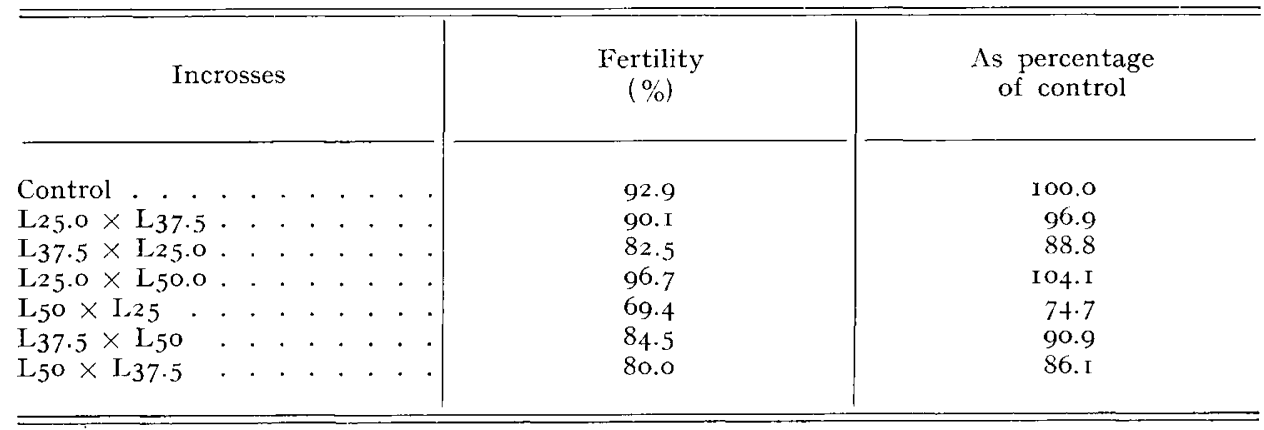




\section{Effect of incrossing on hatchability}

Hatchability of Fayoumi chicks resulting from incrosses showed considerable hybrid vigor. Most of the incrosses had higher hatchability percentage than the control chicks (Table 2). The incross L25 $\times$ L37.5 gave the most positive effect on hatchability, which reached $143.7 \%$ in relation to the control. CoLE and HuTT (I962), and RIzK (I967) proved this positive effect on hatchability.

TABLE 2

Effect of incrossing on hatchability percentage

Effet de la consanguinité suivie de croisement sur le pourcentage d'éclosion

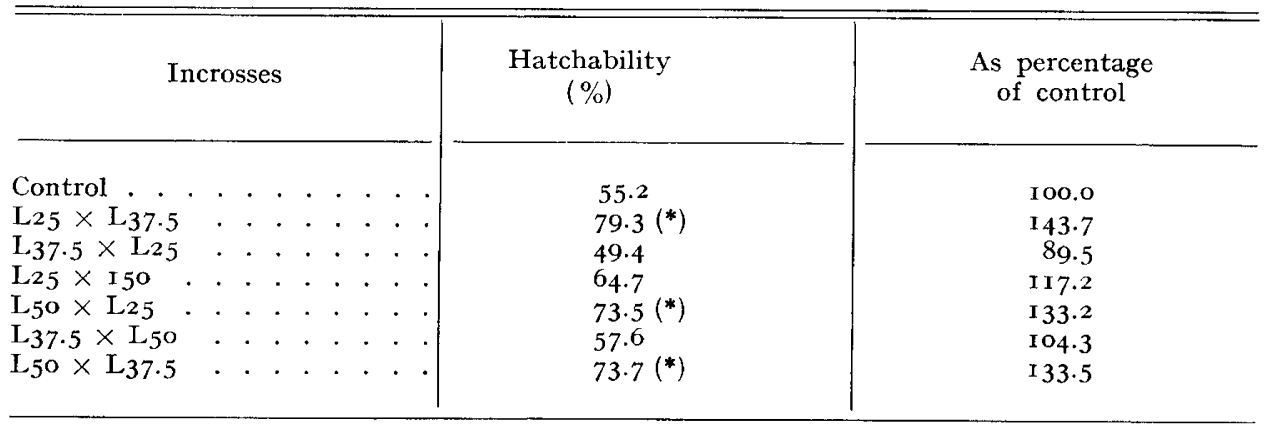

(*) $\mathrm{P} \ll .05$ - significantly superior to control.

\section{Effect of incrossing on viability}

Table 3 presents hybrid vigor in viability of the Fayoumi chicks at different ages. Early viability (i.e. from 0-4 weeks) was improved in some incrosses, where it reached $93.8 \%$ in $\mathrm{L}_{25} \times \mathrm{L}_{37.5}$ compared to $88.0 \%$ in the control. No significant differences were secured among all the means of this early period.

At 8 weeks of age, the viability percentage of the control chicks was 74.4 , while it was 92.3 and 86.4 in $\mathrm{L}_{25} \times \mathrm{L}_{37.5}$ and $\mathrm{L}_{50} \times \mathrm{L}_{37.5}$, respectively. Although there was a marked difference between the incrosses and the control, yet it was statistically not significant. This may be due to the small number of replicates.

At 16 weeks of age, the viability percentage of the control chicks was 67.5 and this figure is low comparing with the figures given in standard breeds. This revealed its lack of genetic potentiality concerning high viability. However, some incrosses gave desirable results and viability percentage reached 84.6 at I6 weeks of age $\left(\mathrm{L}_{25} \times \mathrm{L}_{37.5}\right)$. This figure was equal to $125,3 \%$ in relation to the control and such increasing in some incrossbreds could not be ignored. Similar results were obtained by BRILES and KRUEGER (I955). These results gave the possibility for improving the native breed from the viewpoint of the viability by detecting the most efficient incrossbreds. 


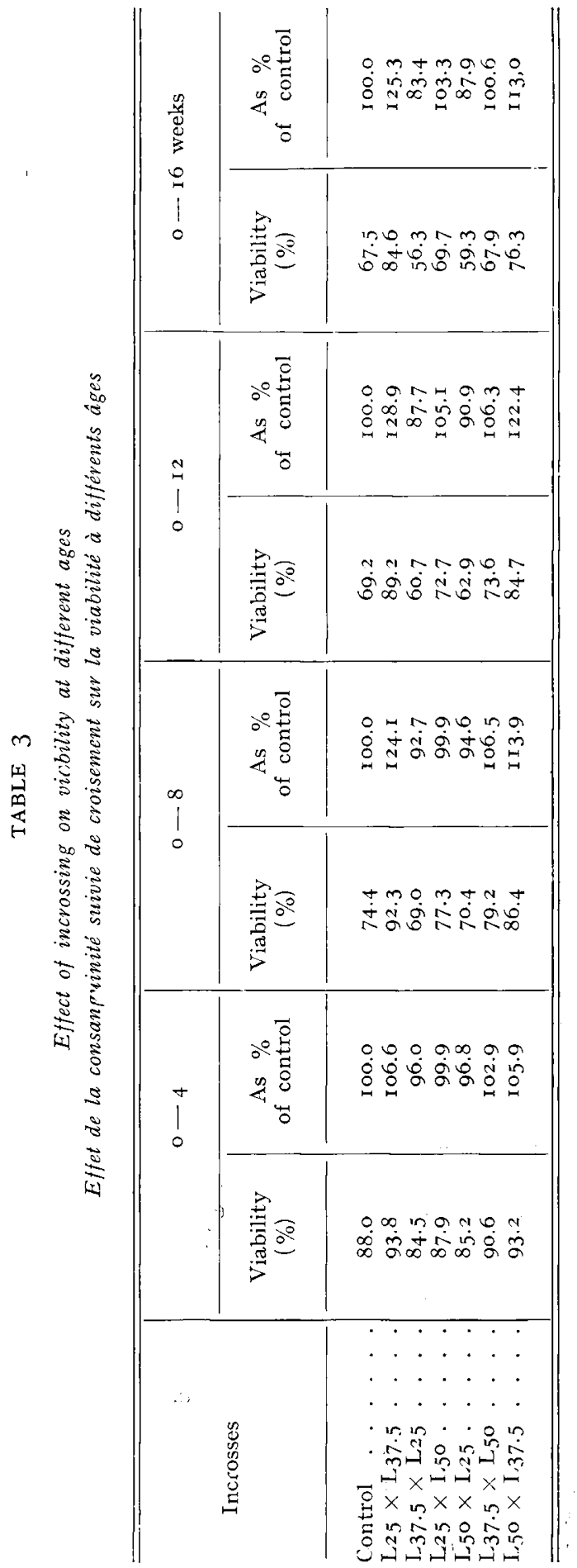




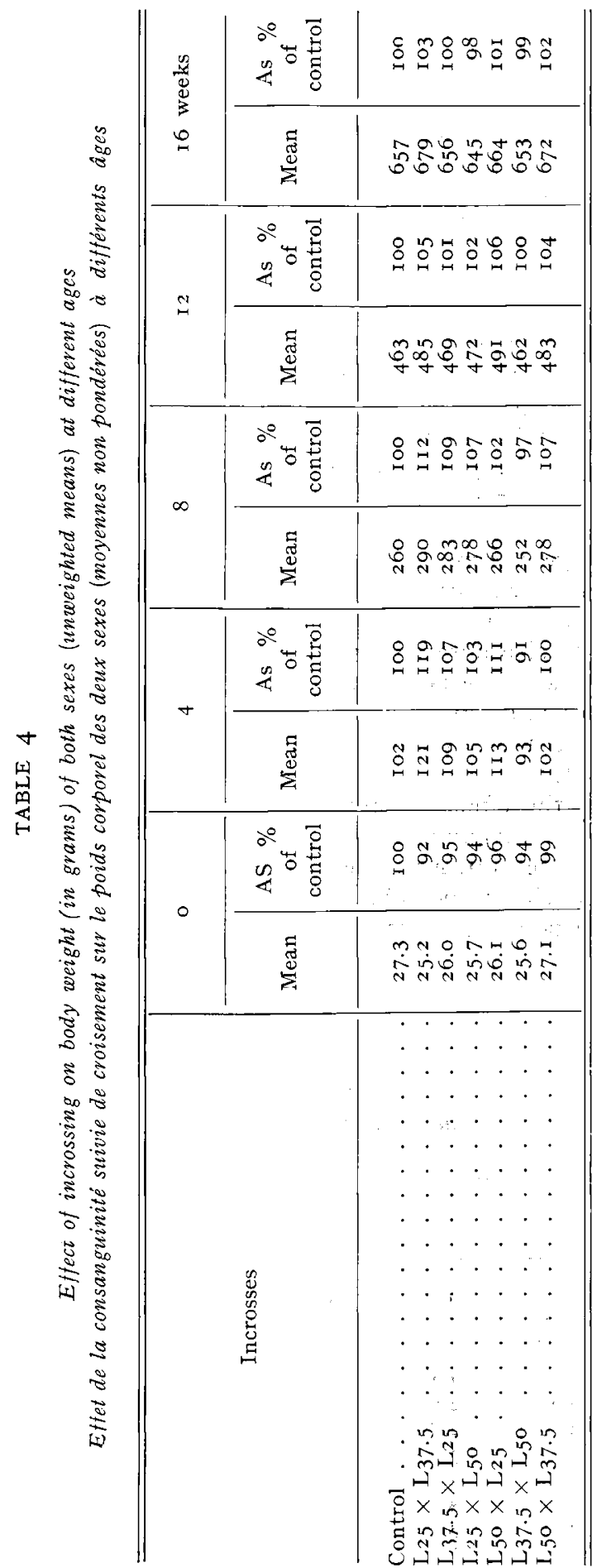




\section{Effect of incrossing on body weight}

Meat production of chickens is considered as a short way to solve the meat shortage in some countries. Hybrid vigor in body weight is widely used in broiler industry and almost all the broilers produced now are hybrids. Table 4 presents body weight of incrossbred chicks in different systems of mating.

At hatching day, almost all the incrossbred chicks were lighter than the control ones. The unweighted mean of both sexes of the control chicks was 27.3 grams and it was 25.2-27.I grams in the incrossbreds. This may be due to maternal effect, where chick weight is largely affected by egg weight and all the inbred dams were lighter than their corresponding controls.

At 4 weeks of age, hybrid vigor became obvious and some incrosses were heavier than the control. It was noticed that the body weight mean of both sexes of control chicks was I02 grams while it was I2I grams in L25 $\times$ L 37.5 incross. In other words, this incross had body weight equal to II $\%$ in relation to the control one.

At 8 weeks of age, the mean of body weight was 260 grams in the control while it varied from 252 to 290 grams in the incrossbreds. The heavier incross (i.e. L25 $\times$ L 37.5) had body weight equal to II $2 \%$ in relation to the control chicks. The same trend was also observed in body weight at I2 weeks of age.

At 16 weeks of age, the body weight mean was 657 grams in the control and varied from 645 to 679 grams in the incrossbreds. Although most of the incrossbreds were heavier than the control chicks, yet the differences among these means were not significant.

To summarize the effect of incrossing on body weight, it was noticed that heterosis in crossbred Fayoumi became less obvious as chicks advanced in age and it was more pronounced during the early period when the growth rate was high. On other words, alleles responsible for early growth rate (during broiler age) showed a great response to incrossbreeding.

TABLE 5

Effect of incrossing on feed efficiency

Effet de la consanguinité suivie de croisement sur le rendement alimentaire

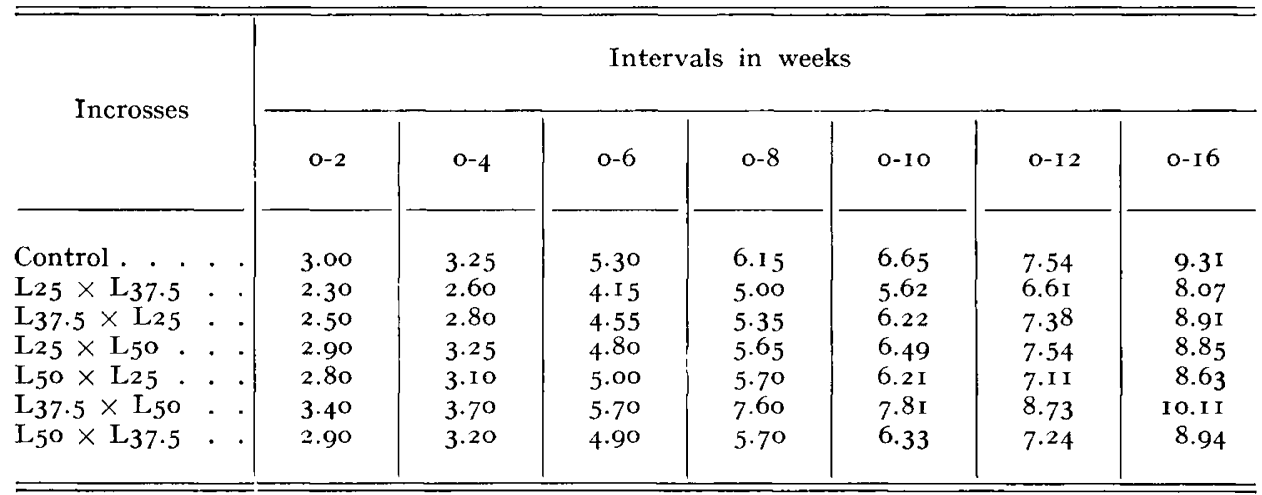




\section{Effect of incrossing on feed efficiency}

Modern trends in poultry production have clearly emphasized the need for research on the efficiency of feed utilization in chickens where feed cost is the largest single item of total cost. At 8 weeks of age, feed efficiency of the incross L25 $\times$ L37.5 was 5.000, while it was 6.I5 in the control chicks (Table 5). Most of the incrossbreds (except L $37.5 \times \mathrm{L}_{50}$.0) showed better feed efficiency than controls. Similar results were reported by MARShaLl and QuisenberRY (I959).

At I6 weeks of age, feed utilization was less efficient and this way be due to low growth rate of the chicks at this older age $\left(^{*}\right)$. Units of feed required to produce one unit of gain were 9.3I in the control and varied from 8.07 to Io.II in the incrossbreds. $\mathrm{L}_{25} \times \mathrm{L}_{37.5}$ was the most efficient incross and its feed efficiency was 8.07 . These results showed that it was possible to reduce the amount of feed required per unit of gain by incrossing and detecting the most efficient incrosses.

Reçu pour publication en mai 1977.

\section{Résumé}

\section{Hétérosis dans des croisements de lignées consanguines de Fayoumi}

Le but de cette expérience était d'étudier l'effet du croisement de lignées consanguines de Fayoumi sur leur aptitude à se combiner. Les résultats peuvent être résumés comme suit :

Le pourcentage de fertilité était 96,7 dans le croisement L25 $\times \mathrm{L}_{5}$ o comparé à 92,9 chez le témoin non consanguin.

Certains croisements $\left(\mathrm{L}_{25} \times \mathrm{L}_{37,5}\right)$ avaient un effet positif considérable sur le taux d'éclosion, l'améliorant de $43,7 \%$ par rapport au témoin.

A I 6 semaines d'âge, le pourcentage de viabilité du témoin était 67,5 , alors qu'il atteignait 84,6 dans le croisement $\mathrm{L}_{25} \times \mathrm{L}_{37}, 5$.

Le croisement le plus lourd (L25 $\left.\times \mathrm{L}_{37}, 5\right)$ avait un poids corporel égal à I I 8, I I 2 et 103 p. Ioo du témoin respectivement à 4,8 et 16 semaines d'âge. L'hétérosis pour le poids corporel était moins marqué à mesure que les poulets avançaient en âge.

Le croisement améliorait le rendement alimentaire des poussins Fayoumi.

Ces résultats montrent la possibilité d'améliorer cette race locale par consanguinité et croisement, et de déceler les croisements les plus efficients.

\section{References}

Briles W. E. and Krueger W. F., r955. The effect of parental B blood group genotypes on hatchability and livability in Leghorn inbred lines. Poult. Sci., 34 : 1182.

COLE R. K. and Hutt F. B., I962. The effect of continued selection in pure strains upon their combinability. Poult. Sci., 4I : I636-1637.

Marshall M. M. and Quisenberry J. H., I959. Factors affecting feed efficiency for egg production in selected strains of caged layers. Poult. Sci., 38 : 757-766.

RIzK Y. G., 1967. The effect of inbreeding and crossing on production characters of the Fayoumi chicken. Ph. D. Thesis, Faculty of Agric., Univ. of Alexandria.

Snedecor G. W., 1959. Statistical Methods Iowa State College Press, Ames, Iowa.

(*) The growth rate of Fayoumi strains is relatively very low in comparison with commercial standards (this being due partly at least to the hot climatic conditions). Thus the marketing age is often I 6 to 20 weeks of age. 